\title{
The recycling industry and subsistence waste collectors: a case study of Mitchell's Plain
}

\section{Belinda Langenhoven and Michael Dyssel}

\section{INTRODUCTION}

Over and above its environmental advantages as a waste management strategy, recycling also has advantages for the creation of formal and informal employment. This paper reflects the findings of a survey undertaken in Mitchell's Plain and case studied the factors that impact on recycle-related employment tendencies and opportunities in this area of the Cape Flats. It also revisits the popular notion of recycling-sustainability reciprocity in impoverished and economically marginalised areas. Mitchell's Plain, as a largely dormitory region in the bigger Cape Metropolitan Area (CMA), offers very little employment opportunities. Based on the findings of the survey, this paper argues in favour of recycling as a mechanism for the sustaining of livelihoods for impoverished micro-collectors as well as small recycling-based entrepreneurs in the area and surrounding townships. The recycling industry in Mitchell's Plain depends largely on recyclable household waste generated in the area. Secondary waste sources include waste generated in neighbouring areas such as Khayelitsha and Philippi as well as waste generated by the limited retail and light industrial activities in the area.

The interdependency among waste generating areas, subsistence waste collectors and buy-back centres and/or recycling outlets in the study area displays similar trends as those reflected elsewhere in the world. Waste pickers are however, just like other poor people, often not properly recognised in these interdependency relationships. Khan (1996) believes that subsistence waste collectors are often considered as societal outcasts, despite the very important role that they play in waste management chains throughout the world.

Various studies have shown that there is a positive link between recycling and job creation. In the United States of America, recycling has had a major impact on job creation in local state economies. Jobs gained in this sector far outnumbered jobs lost in other industries. The recycling growth rate in the US in the period from 1967 to 2000 stood at 12.7\% and in Brazil, more than 100 ooo people are said to be living off collecting and selling recyclables. (Institute for Local Self Reliance, 2002). In South Africa, thousands of recycling-related jobs already exist. It is estimated that there is for example more than 37 ooo people earning a living "by picking up cans for recycling" (South African Yearbook 2000/2005: 245). There are virtually no barriers to entry at the waste collection level. A study undertaken in Durban showed that lower income groups practice recycling as a means of job creation and income generation. At the Bisasar Road landfill site, over R66 ooo worth of recyclables, totalling about 260 ooo kilograms, are retrieved each month by about 300 to 400 waste pickers who are earning approximately R300 per family per month (Durban Metro, 1999). 
The extended re-use of essential resources and materials to supplement scarce resources is in essence what recycling is all about. Recycling can be defined as "the process by which materials otherwise destined for disposal are collected, processed, and manufactured or reused" (EPA, 1995: 6-1). It is within this generic definition of recycling that the varied opportunities for the creation of employment on specifically informal and small-business scales are rooted. Waste management processes such as collection, processing, manufacturing and reusing pose, however, major challenges to prospective entrepreneurs. These challenges range from the sourcing of recyclables up to final transactions (recyclable-cash exchanges) at buy-back, recovery or (re)processing facilities. The South African government recognises that recycling can help to sustain the livelihoods of impoverished communities and launched, via its Department of Environmental Affairs and Tourism, a campaign in 1998 to encourage entrepreneurs to open buy-back centres. These are privately owned, market driven facilities where mostly post- consumer, but also pre-consumer waste materials are bought and temporarily stored (City of Cape Town, 2004a). Such facilities can act as catalysts for job creation for subsistence waste collectors. Buy-back centres are to be found in all major centres countrywide. In the Cape Town Metropolitan Area, buy-back centres are primarily located in low-income and high-density areas or in commercial/industrial nodes. At these centres subsistence collectors are mostly paid on an ad hoc basis for the delivering of certain types and grades of recyclables (City of Cape Town, 2004a).

If recycling is seen as a vehicle for Integrated Solid Waste Management (ISWM), then the yardstick by which sustainability is measured, needs more scrutiny. The premise that recycling per se is sustainable as far as the creation of livelihoods is concerned, is therefore problematic. Recycling is generally considered as one of the less dynamic segments of South Africa's informal economy (Chen, Jhabvala and Lund, 2001). Waste recycling can, however, offer development opportunities for communities.

Waste material, if collected with care and upgraded and transformed with quality in mind, can contribute to local income, employment creation and economic development (Institute for Local Self Reliance, 2002). In many countries, the urban poor have been assisting local municipalities in reducing the amount of waste at landfill sites without receiving the necessary recognition. In India, waste pickers, for livelihood reasons, assist an ineffective municipal waste management system, "by collecting and selling waste to waste dealers, they reduce a sizeable quantity of it from going to the landfills and carry out a generous service to conserve resources" (Gupta and Sarka, 2003:1).

In a critique on the casualisation of public sector services in South Africa, specifically waste collection, Miraftab (2004:1) argues however, that casualisation of labour does not address unemployment, but perpetuate "apartheid under neoliberal policies" in the CMA. With poor service delivery rendered in Cape Town's townships, it can be argued that more waste ends up in the informal waste stream and therefore precipitating (by implication) stronger recycling competition among the urban poor. The viability of recycling as a livelihood option is therefore also questionable.

\section{https://repository.uwc.ac.za/}


At the national level there is no legislation in place that compels communities to recycle. Policies and planning documents such as the White Paper on Integrated Pollution and Waste Management (2000) and the National Waste Management Strategy (1999) provides strong guidelines and practical recommendations and it targets the subject of waste minimisation of which recycling forms an important element (City of Cape Town, 2004b). Progress is made, however, towards the implementation of policies to encourage waste recycling. In the White Paper on Integrated Pollution and Waste Management for South Africa, some of the strategic goals and objectives are related to the reduction in the waste stream by ensuring an economic environment that favours recycled materials, and subsidising recycling campaigns in order to make them economically viable (Government Gazette, 2000).

In the Draft Waste Management Plan for the City of Cape Town, one of the premises for the assessment of waste minimisation is the envisaged imposition of mandatory waste separation that would oblige households and businesses to separate waste into various recyclable streams (City of Cape Town, 2004b). South Africa is lagging behind many other countries in terms of waste recovery. It is estimated that the recycling figure for the country is "in the vicinity of 30\%" compared to the $50 \%$ for countries such as Japan and Germany (Hugo, 2004: 186). People involved in this industry vary from the very poor and destitute who waste pick from bins and landfills, to the more established collectors who own their own motorised transport.

Recycling in economically deprived areas such as Mitchell's Plain on the Cape Flats is facing additional challenges that are related to more fundamental socioeconomic conditions (such as poverty and unemployment) and environmental variables (weather conditions) that prevail locally. As a dormitory area without major industrial, commercial and service-rendering opportunities, the source for waste generation is largely domestic. Mitchell's Plain represents a relatively poor community in the (CMA). Unemployment rates in the study area range from $17 \%$ in the middle-income suburbs to as high as $38 \%$ in lower income suburbs. The surrounding areas of Philippi and Khayelitsha (Figure 1) have many informal settlements with even "higher estimated unemployment rates and poverty" (Cape Times, 2004:3).

Poor socio-economic conditions that prevail in the area presumably precipitate limited expenditure on disposable items and subsequently less generation of waste. The waste feed on which the formal recycling industry is based, is therefore far less promising than in other regions of the CMA. In such regions the waste generating base is more diverse and the potential waste feed stronger and more secure. The space-place dimensions of recycling and its potential benefits can 
Figure 1 - Distribution of buy-back centres in Mitchell's Plain.
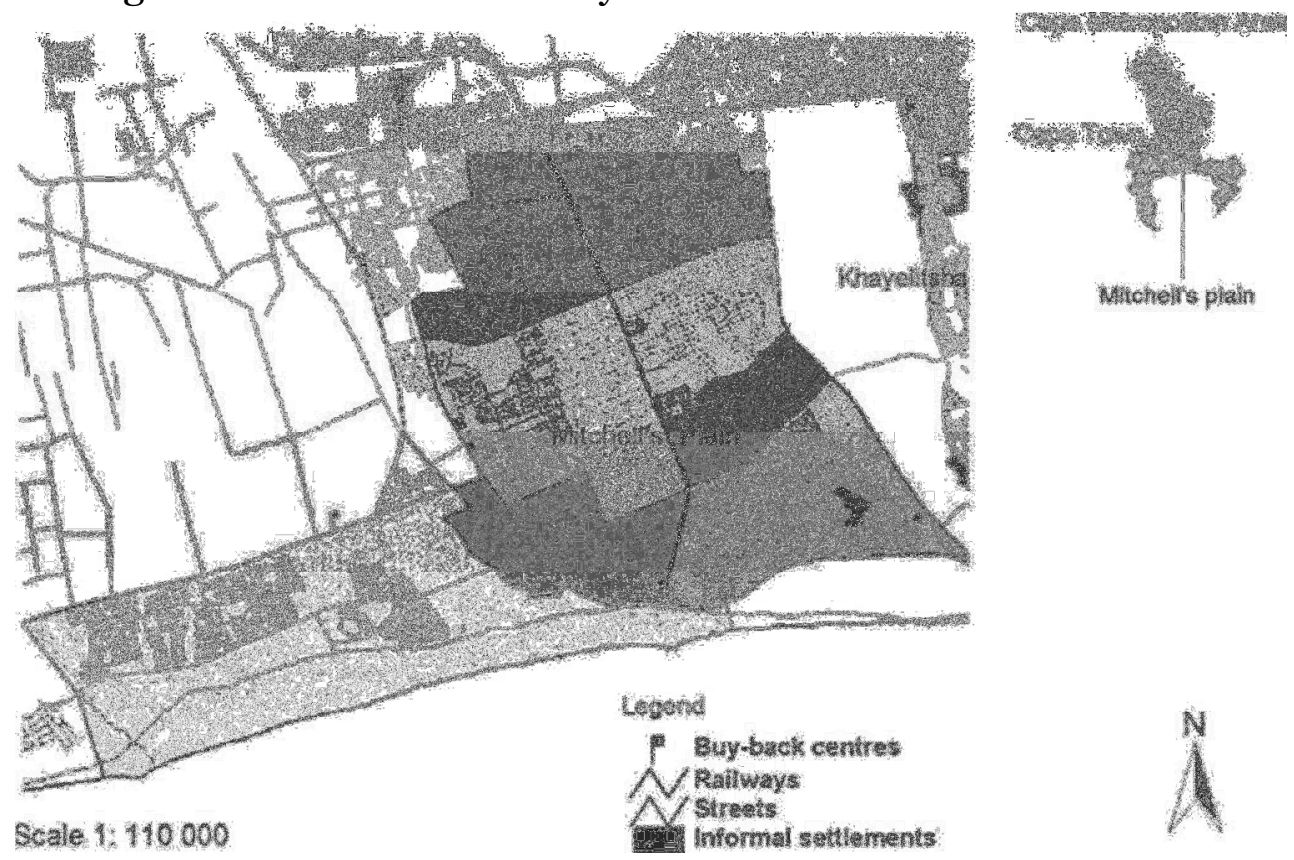

therefore be related to the spatial, social, economic and infrastructural legacy of urban (apartheid) planning in the CMA. In this context, the paper therefore also analyzes and revisits recycling as a basis for pro-poor employment creation and vehicle for ISWM. The latter can also be seen as an "analytical framework for understanding waste management systems; as an assessment methodology for predicting feasibility and sustainability; and as a description of an urban development process" (Scheinberg, 2001:8).

Drawing on interviews, primary information and data were obtained from the respective recycling companies. It included records of volume trends, number of payouts per day/week and average amounts paid out. Impromptu discussions with micro-collectors (who were willing to provide information) also supplemented a questionnaire that was administered for other micro-collectors. Twenty-seven collectors (across gender and age boundaries) were engaged in the survey on a convenient sampling basis.

\section{THE RECYCLING INDUSTRY IN MITCHELL'S PLAIN}

The recycling industry is generally comprised of two tiers. The first tier relates to an intermediate market that includes collectors, processors, brokers and converters. The second tier relates to end-use markets that use recovered material as feedstock to manufacture new products (EPA, 1995). The industry can also be classified on the basis of a material-specific market structure in which all the recyclable material is grouped into five major categories namely paper, glass, plastics, scrap metal and waste tyres. In the CMA the market structure (Table 1) for the recycling industry is comprised of six different role player categories (City of Cape Town, 2004a). 
Buy-back centres, as break-in-bulk and transaction points, are located throughout the metropolitan area (mostly in waste catchment areas, as well as in industrial and commercial nodes) and act as satellite stations for the recycling industry.

There are five multiple buy-back centres and a plastic buy-back processing plant in Mitchell's Plain (Table 2). The sorting depot (initially a Department of Environmental Affairs and Tourism sponsored Section 21 Company) has been transformed into a privately owned buy-back centre. A Section 21 company is a non-profit driven organisation that is supported by government or donor funding. The plastic processing plant also buys plastic waste from collectors and reprocesses it into pellets that are then sold to end-user industries.

Four of the six enterprises are located in the Mitchell's Plain industrial region. Another one is located in Philippi, a zone that displays typical transitional land use mixes, namely farming, housing, industrial and wholesale functions. Only five of the six establishments were prepared to divulge information required for the study. The manager of the sixth enterprise was never available for interviewing purposes. 


\begin{tabular}{|c|c|}
\hline ROLE PLAYERS & FUNCTIONS \\
\hline Micro-scale collector & $\begin{array}{l}\text { Any individual, usually unemployed and homeless, who collect } \\
\text { waste with the help of a trolley or bag. Recyclable materials from } \\
\text { these micro-collectors come either directly from factories or } \\
\text { businesses in industrial or commercial hubs (pre-consumer } \\
\text { waste) or are received from post-consumer sources such as } \\
\text { household waste bins and landfills. They mostly sell to } \\
\text { middlemen or buy-back centres due to transport limitations and } \\
\text { only receive a fraction of the price paid by the big recyclers. }\end{array}$ \\
\hline Small-scale collector & $\begin{array}{l}\text { Independent individuals with motorised transport that } \\
\text { enables them to collect waste from industrial outlets. They } \\
\text { usually target pre-consumer waste sources. Small-scale } \\
\text { collectors are able to react quickly to price fluctuations in local } \\
\text { recycling markets, which strongly determine the type of } \\
\text { materials they collect and to whom they sell recyclables. }\end{array}$ \\
\hline Large-scale collector & $\begin{array}{l}\text { Collectors who manage a fleet of collection vehicles (large } \\
\text { trucks) and have premises where collected material is sotted } \\
\text { and often to some degree processed (e.g. pre-sorting and } \\
\text { granulating of plastic waste). }\end{array}$ \\
\hline Buy-Back centre/depot & $\begin{array}{l}\text { A location where mostly post-consumer but also } \\
\text { pre-consumer waste materials are bought and temporarily } \\
\text { stored. Buy-back centres are often directly supported by a } \\
\text { recycling firm that offers start-up finance, a location and } \\
\text { infrastructure for an individual to get started and to collect } \\
\text { waste for them. Most buy- back centres accept all types of } \\
\text { waste that are sorted on the premises and then sold to the } \\
\text { respective recyclers. }\end{array}$ \\
\hline $\begin{array}{l}\text { Community/NGO } \\
\text { drop-off }\end{array}$ & $\begin{array}{l}\text { Enterprises established based on one or the other community } \\
\text { need. Waste received by here is often donated by households } \\
\text { or businesses in an area. They often sell directly to big } \\
\text { recycling companies. }\end{array}$ \\
\hline $\begin{array}{l}\text { Recyclers / End-use } \\
\text { buyers }\end{array}$ & $\begin{array}{l}\text { Important companies to which collectors and buy-back centres } \\
\text { sell their waste materials to. }\end{array}$ \\
\hline
\end{tabular}

Source: compiled from Status Quo Report of the City of Cape Town (2004a).

\section{Recycling Business Structure}

This section deals with the nature of buy-back centres and tendencies in the recycling industry in the study area. Three of the six enterprises (centres 1,2 and 3) accept all types of recyclables. Two (centres 4 and 5) specialise in ferrous and non-ferrous metals. The sixth enterprise specialises in the purchasing of plastic waste from collectors that is processed into granules and then sold to local end- user markets elsewhere (Table 2). The lucrative metal market drives and sustains the two metal recycling facilities. The stable demand and

\section{https://repository.uwc.ac.za/}


little fluctuations in the market price for recycled metals strengthen these businesses. The reason for the specialisation in plastics at the sixth enterprise is to be found in the fact that there is a niche for recycled plastic in the Mitchell's Plain area.

The supply-chain and flow of materials to recycling facilities in Mitchell's Plain and those elsewhere are largely based on two origins (Figure 2). The first origin relates to post-consumer sources (household and commercially-used waste) supplied mainly by micro-collectors and the other one relates to pre-consumer waste (discarded excess waste materials from industrial and commercial processes) supplied by both micro and small-scale collectors.

In the case of multiple-product centres, paper and cardboard are by far the bulkiest commodities bought from collectors who collect predominantly from households. Paper and cardboard are also those enterprises' strongest base and biggest revenue earners for collectors. Table 2 is a summary of the types of recycled material handled by the studied enterprises, as well as how long they were in operation. Most of the enterprises have been in operation for more than ten years. The newer facilities (centres 3 and 5) that were established most recently are branches of established enterprises. It is evident that the study area has a relatively long history of recycling practices and the fact that new branches of existing ones have been established recently, indicates a level of growth in presumably both the supply and demand side of the recycling industry in the area. An interesting observation is the non-intake of cans by facilities in the study area especially against the background of a relatively big consumer market and presumably also good potential for tinned and canned commodities. 
Figure 2 - The flow of recyclables

PRE-CONSUMER WASTE

POST-CONSUMER WASTE

HOUSEHOLD WASTE

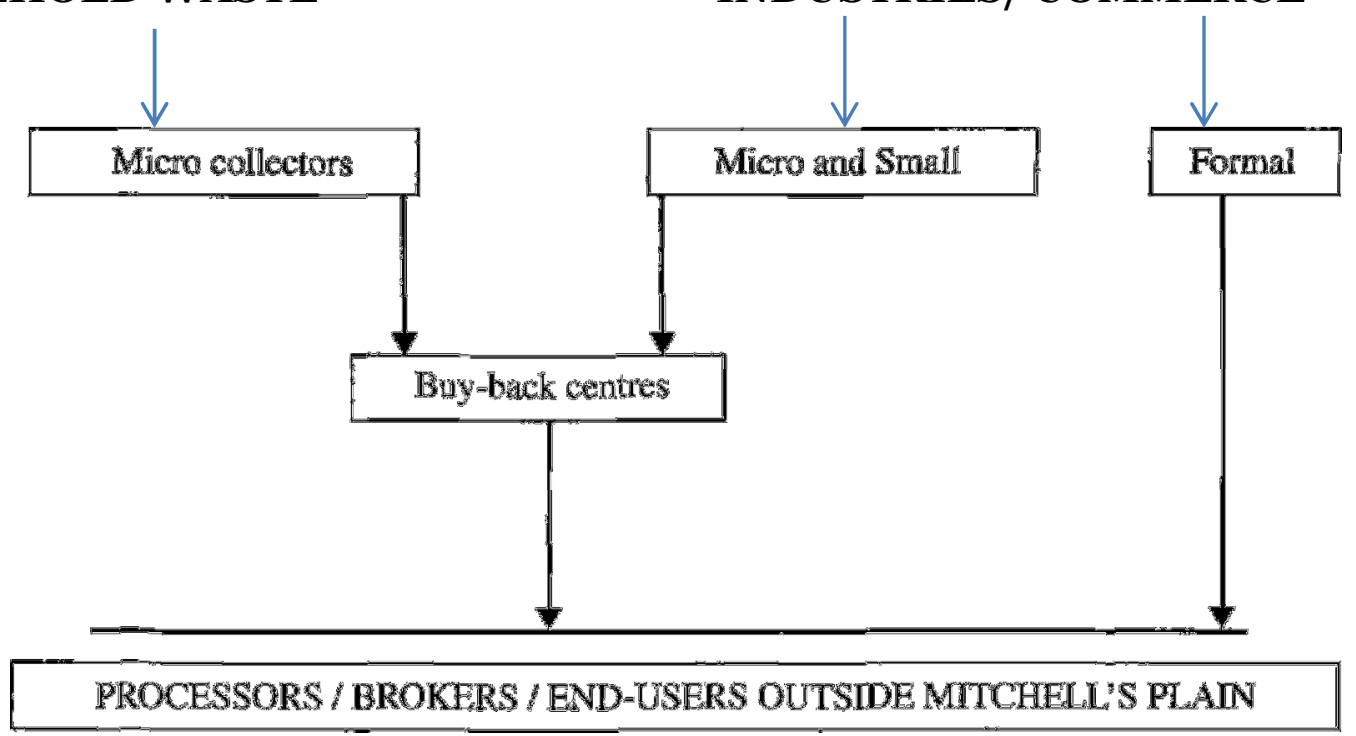

INDUSTRIES/ COMMERCE

Adapted from City of Cape Town, 2004a

HOUSEHOLD WASTE

Table 2 - Buy-back centres, recyclables and business age.

\begin{tabular}{|l|l|l|l|l|l|l|}
\hline $\begin{array}{l}\text { Buy-Back } \\
\text { Centres }\end{array}$ & Paper & Plastic & Glass & Cans & Metals & $\begin{array}{l}\text { Years of } \\
\text { operation }\end{array}$ \\
\hline Centre 1 & $*$ & $*$ & $*$ & & $*$ & 12 Years \\
\hline Centre 2 & $*$ & $*$ & $*$ & & $*$ & 10 Years \\
\hline Center 3 & $*$ & $*$ & $*$ & & $*$ & 4 Months \\
\hline Centre 4 & & & & & $*$ & 18 Years \\
\hline Centre 5 & & & & & $*$ & 2 Years \\
\hline Centre 6 & & $*$ & & & & 18 Years \\
\hline
\end{tabular}


Size

All the enterprises in the study area started off with between six and twenty employees. These figures have increased over the years as these enterprises have grown. The physical sizes of their premises varied between 450 and 1000 square meters.

\section{Location}

The more established enterprises are all located in the industrial area of Mitchell's Plain within a 500-meter radius from each other. Zoning regulations, affordable letting space and the industrial area's proximity to the commercial zone of the area seem to have been the main motivations for the site selections exercised by the entrepreneurs. The locations are regarded by all role players to be ideal, despite the competition, as it is land-marked by all collectors as the recycling zone.

\section{Government Assistance and Expansion}

The ages of the older enterprises (with business ages from ten to eighteen years) imply that they were established during a period in which there was little government assistance for emerging entrepreneurs. Currently, the Department of Environmental Affairs and Tourism (DEAT) does provide financial support to Section 21 companies, such as community-based and non-governmental organisations. The enterprises in the study area are privately owned and can therefore not tap into this source of financing to expand their operations. There were also no government policies that could benefit them in terms of increasing the amounts of recyclables or in terms of regulating any form of price collusion by the bigger companies who monopolise the industry.

Only one enterprise received government assistance from the DEAT when it was originally established as a sorting depot and a Section 21 company. It has since lost the grant (according to the manager) and has become a branch of one of the buy-back centres. The other enterprises have not received any assistance and were also not aware of any such assistance at that stage.

Only three enterprises have expanded their enterprises in the past through the acquisition of more equipment, extending premises and the opening of other branches elsewhere. The expansion can partly be attributed to the population growth in the area, unemployment and urbanisation as well as increases in the demand for recycled material. Spatial Manoeuvring

The motivation for establishing branches at other locations in Mitchell's Plain was a direct result of the fierce competition as the older enterprises are all located within close proximity to each other. The competition and animosity among owners were fuelled by one of the enterprises being bought by a previously advantaged individual who owns a chain of buy-back centres elsewhere in the CMA and who has increased his payouts for recyclables to gain a bigger market share. This enterprise could do it as it has its own transport compared to the others that were largely dependent on contracted or hired transport.

\section{https://repository.uwc.ac.za/}


There appears to be a strong sense of territoriality amongst these enterprises as well, especially those that have been in business for more than ten years. They regard the new owner as an outsider based on his race and resource base, and feel that the area should be reserved for previously disadvantaged communities. In protest they have written to various authorities to complain about the situation. Other operators have also expressed desire to expand their operations by opening branches in other suburbs of Mitchell's Plain, also as a result of the competition. The idea is to present a spatially more convenient option to collectors who are waste-picking in certain suburbs/sections of Mitchell's Plain at certain days of the week. By off-loading/selling their material in an earmarked area, they would reduce the distance and time they have to travel considerably.

Dyssel (2001) highlighted the importance of spatial manoeuvring through an analysis of the relationships between mode of transport, prices paid at recycling facilities and recyclables that need to be transported. Given the mode of transport of the collectors (predominantly by trolley and on foot), as well as other considerations like theft of material by criminals who operate near the centres, many prefer the option of suburb-specific facilities. This would naturally increase the market share of enterprises at specific times of the week in different localities, if the prices offered for materials are competitive enough.

\section{Job Creation Capacity}

The number of workers per establishment varies from enterprise to enterprise. More workers are normally employed where processing is done on the premises (e.g. plastic reprocessing). In most cases this number has increased over the years. Casual labour is often employed when there are staff shortages as a result of worker absence or rare peak business periods.

The number of collectors/visitations also varies from enterprise to enterprise-it ranges from thirty to fifty collectors/visitations per day at the newly established facilities and from 100 to 150 collectors/visitations per day at the more established multi-material buy-back centres. Enterprises are constantly trying to poach each other's customers by offering better prices or by offering to collectors refreshments such as soup or coffee on cold days. Some collectors sell certain recyclables to certain buy-back centres because the latter offer better rates for certain materials. Some will visit a centre more than once a day. It is thus difficult to determine the exact number of collectors based on entries made in the cash registries of these centres. Managers of the more established enterprises have detected an increase in the number of collectors over the years and they attribute it largely to the high unemployment rate in the region, as well as the increase in the number of people residing in the larger Mitchell's Plain area.

\section{VOLUME TRENDS AND THE SUPPLY AND DEMAND FOR RECYCLABLES}

The following section illustrates the tendencies observed and recorded at the various facilities.

\section{https://repository.uwc.ac.za/}




\section{Volumes and Capacity}

All the enterprises indicated that they were operating below their capacity. Their potential capacities were similar (based on the sizes of their premises). Some quoted potential capacities for paper and cardboard as being in excess of approximately fifty to sixty tons per week. This figure was arrived at by taking the following into account: size of the premises, the amount of weighing scales, storage containers, as well as transport means. However, given the nature of the collection process in this region, the number of enterprises, the strong competition among buy-back centres, as well as other market related factors, most enterprises operates below their potential levels. Managers indicated similar factors, which include competition from other enterprises in terms of pricing, weather conditions particularly with regard to cardboard and paper, availability of transport, number of collectors and location.

\section{Price Fluctuations}

The prices paid for recyclables impact on the volumes collected. These prices are determined by fluctuations in supply and demand. Recently there has been a slump in the demand for paper, which has decreased the prices paid for paper-related recyclables. Such market-lowered prices are subsequently then also reflected in prices paid to collectors who often, as result of that, have to look for other ways of supplementing their income from recyclables in order to earn a living. The situation also places pressure on buy-back centres that, as a means of temporarily shouldering a slump, attempt to stockpile material until the prices improve. If paper material is the main source of income of an enterprise, a prolonged slump could lead to a diminished capacity to operate competitively when funds to purchase material run low.

Managers at the multiple-material buy-back centres indicated that paper has been their bulkiest commodity and that they are concerned about price slumps. During the survey the actual price changes have been difficult to access and assess because operators were not prepared to disclose information. Some have indicated that they may have to reduce the number of workers in order to stay in business. This is a clear indication of the relationship among capacity, prices and employment creation, as well as security of employment.

\section{Weather Conditions}

Weather conditions have a significant effect on multiple-material centres that depend heavily on paper as their anchor material. Given the fact that in the study area most paper material is recovered from household waste and the fact that micro-collectors predominantly use open, non-motorised transport such as trolleys and push carts as means of transport, material is often damp by the time it reaches the buy-back centres. This has a significant impact on the livelihood of the subsistence collectors who may be short-paid at buy-back centres. Between ten and twenty-five percent is deducted from the weight if the material is wet and collectors are then being paid accordingly. Some micro-collectors are

\section{https://repository.uwc.ac.za/}


thus reluctant to collect or sell waste during wet weather conditions. However, many collectors cannot afford not to collect as it supports their daily subsistence. The same dilemma faces buy-back centres when they in turn sell to the bigger paper processing companies like Nampak, Mondi and Sappi. Rainy weather can therefore result in a decrease in the supply of paper material to operators at the lower and higher ends of the recycling chain.

\section{Demand and Supply}

There is a demand for most recyclables in the study area and all operators have indicated that their volumes have increased over the years as a result of an increase in the demand for recyclables from big processing companies. However, all of them attributed price fluctuations, and by implication the health of their businesses, to the general volatility of the local recycling industry. Some also view this volatility with scepticism and feel that there might be collusion amongst the bigger buyers and processors. The slump in the prices for paper material has persisted for some time and certain material (such as mixed paper) is therefore not that attractive for big paper processing companies. This affects subsistence collectors, as they have to collect more selectively than before, which is often more time consuming. It often means that they receive less for their material than during more favourable and diverse market conditions.

The supply of material has always been lower than the demand with the exception of paper. In this instance buy-back centres stockpile the paper until market conditions are more favourable. Daily intake of material is only limited by cash flow. If cash flow problems occur, collectors are given cash slips which they can redeem later when cash is available. As a crime precautionary measure, limited amounts of cash are kept on the premises of buy-back centres. On the other hand, due to the harsh competition they do not turn collectors away (hence the cash slip) and make every effort to pay them as soon as possible. This situation applies particularly to the new branches that are located in the quieter, non-industrial areas. There are no mandatory regulations in the region forcing households to recycle. This severely reduces the amount of waste that could be supplied to these centres.

\section{Number of Collectors and Employment Seasonality}

It is evident that the relationship between buy-back centres and collectors are symbiotic in that both can benefit from each other. The success of these centres rests, amongst others, on the amount of material supplied to them by collectors. A reduction in the number of collectors selling to them means a decrease in the supply of material and a potential decrease in profits. The strong competition among the three multiple buy-back centres located in close proximity to each other has resulted in increased prices for recyclables in order to attract more collectors and by implication securing some sort of consistency in supply. Other fringe advantages such as the offering of refreshments to collectors on cold and warm days have also being embarked upon to try and secure supply.

\section{https://repository.uwc.ac.za/}


The amount of collectors operating in the study area is also affected by external factors such as peak economic periods during the December holidays and the Easter period, when consumer spending is at its highest. This has varying effects on the buy-back centres. Some experience a decrease in collector visits, especially the ones specialising in pre-consumer waste from factories that close over the mid-December and early-January period. Others experience an increase in the influx of collectors as more post-consumer waste is generated during those periods. Operators have indicated that some collectors even find temporary employment during that period but resume collecting waste at the end thereof.

Another employment tendency that was reported on by operators was the casual component of collectors. In early to mid-January the number of collectors reportedly increases as many formally employed people are embarking on recycling as a means of supplementing their income until they start working formally in the latter part of January. This indicates that there are casual-seasonal waste collectors who do supplement their income with this practice and subsequently impacts on the volume of material received at buy-back centres.

\section{COLLECTION PROCESS AND COLLECTORS}

In addition to the tendencies discussed earlier, the following information was also obtained from the questionnaires administered, interviews conducted and observations made.

\section{Source of Recyclables}

All collectors interviewed indicated that they collect the bulk of their material from household refuse bins. It was also indicated that some shop owners have made prior arrangements with formal collectors. This implies that curbside recycling is the main source of waste supplied to the buy-back centres in Mitchell's Plain. The waste is therefore predominantly post-consumer waste. It also implies that most of the pre-consumer, industrial and commercial recyclables generated in Mitchell's Plain are not being processed by these enterprises. They may be collected by formal collectors or they are sold directly to the big processors elsewhere.

Curbside collection takes place when refuse bins are placed on roadsides so that refuse collectors can have access to them. This presents the only opportunity for waste collectors to pick recyclable items from waste bins and bags. Collectors have to start operating before seven o'clock in the morning before the arrival of municipal waste-collecting trucks. Micro-collectors also travel to different suburbs daily in order to salvage recyclables. Because households are not compelled to separate their waste, collectors have to sort through waste which could potentially be hazardous to their health, especially as they do not wear protective clothing. They are also threatened by many homeowners who regard

\section{https://repository.uwc.ac.za/}


them as a nuisance and fail to understand the role they play in helping to reduce the amount of waste in the formal and informal waste streams.

\section{Distances Travelled}

The distances travelled by collectors vary depending on the different days of the week. This in turn, depends on which suburbs in Mitchell's Plain have waste removal on a particular day and from which area the collector originates. Most of the respondents reported that they leave home at four o'clock in the morning to sort through waste bins before the latter are collected by municipal refuse trucks. These distances could range from ten to twenty kilometres daily. These distances are quite extensive in comparison to other areas and results from other studies. Dyssel (2001) showed that collectors, operating elsewhere in the CMA, who are using trolleys as their means of transport travel on average between five and ten kilometres daily.

The establishment of a buy-back centre along Spine Road (one of the main arterial routes running through Mitchell's Plain) has greatly reduced the distances travelled by collectors who reside in the western sections of Mitchell's Plain. For example, travelling from Dagbreek camp in the suburb of Westridge to Strand- fontein to collect material and then having to travel to the industrial area to sell would be in excess of fifteen kilometres. With the branch on Spine Road, this distance is reduced by at least five kilometres.

\section{Mode of Transport}

The majority of the respondents made use of a shopping trolley to transport their material. Some have customised their trolleys by removing the upper grid and replacing it with a broader base to accommodate more material. Many resort to this practice in order to prevent the confiscation of trolleys by security companies. These companies are employed by big retail stores to retrieve stolen shopping trolleys particularly in the Mitchell's Plain area where trolleys are also used by informal traders (e.g. shebeens and spaza shops). The horse cart is used predominantly by collectors of scrap metal as their items are too heavy and bulky to be transported by push cart or by trolley.

\section{Collection Unit}

Seventy percent of the respondents indicated that they collect their own material. They might travel in groups at times but each person collects his or her own material and uses his or her own trolley. This differs from other regions where the lack of trolleys and/or closer community relations resulted in collection teams of more than two persons. Of the thirty percent who collect in teams, half is doing so as a result of spousal or family ties. A third shared a home, while some share a trolley(s).

\section{https://repository.uwc.ac.za/}


In terms of waste collected as a group, the respondents who had non-spousal relationships would share their income at the pay point. The researchers have encountered no other non-financial agreements amongst respondents who operated as a collection team. Even though some respondents share a home, the money is divided amongst them at the pay point.

\section{Problems Encountered}

On a multiple-response question respondents indicated quite a few problems that they normally encounter while collecting waste. The majority of respondents cited weather conditions as a major problem. Paper material often forms the bulk of their cargo and buy-back centres deduct money if the material is damp. Many respondents also complain about the way they are treated by homeowners who threaten and often assault them. It was also indicated that homeowners have sometimes unleash their dogs on subsistence collectors. This hostile relationship between homeowners and collectors may be indicative of the fear of crime, racism and previous unacceptable behaviour by collectors who might have littered the neighbourhood while waste picking. Some respondents indicated that they have no problems, but remarked that they collect recyclables as a result of being unemployed.

The problem of decreasing prices paid for their material was also a big concern for collectors. A drop in prices makes the collection process so much more difficult and it often means having less money to purchase a meal or to satisfy other needs. Many collect on a daily basis to purchase essential foodstuff. Others literally live from "hand to mouth". Some stated that the approximate eight rand collected daily will be used to satisfy various dietary needs on a rotational basis.

Robbery was also cited by many respondents as being a problem. Some are robbed of the little money that they have earned for the day. In some instances criminals remove valuable metals from collectors' trolleys while they are queuing at buy-back centres. Some-buy back centres have subsequently placed security guards at the entrance to premises in order to protect their suppliers.

Other, more personal problems recorded, include hunger while collecting, since they spend so many hours on the road and may only have money to purchase a meal later in the day. This is a clear indication of the level of destitution among some of the collectors. Health issues related to general fatigue, aching backs and limping while walking, were also raised.

\section{Period of Involvement}

Respondents were requested to indicate how long they have been engaging in waste collection on a continuous basis. If there were breaks in the period, the researchers then only recorded the new period from which they started. The largest percentage of respondents (65\%) has been collecting for more than three years while $35 \%$ has been

\section{https://repository.uwc.ac.za/}


collecting for ten years and more. This suggests that respondents were able to sustain their livelihoods from recycling for significantly long periods of time. It also indicates that the majority of respondents are experienced collectors who have not been employed in the formal sector for long periods of time.

Since $45 \%$ of collectors are between 50 and 65 years of age, the chances of them getting formal employment are extremely remote and one can therefore infer that they will continue to collect waste until they are eligible for a government pension or disability grant. All respondents, even those who have been collecting for more than ten years, have indicated that they would prefer to be employed in the formal sector and only engage in waste recycling as a last resort to sustain their livelihoods.

\section{Income Generated}

Seventy-five percent of respondents earn less than R80.oo per week, while only fifteen percent indicated that they earn in excess of R100.00 per week through the selling of recyclables. The low income derived from waste recycling implies that the respondents are living on an income that is well below the breadline. It reflects the abject poverty and desperation of these people who collect waste to survive. Less than $50 \%$ of those who have been collecting for more than ten years earn in excess of R100.oo per week. One can therefore conclude that while experience does play a role in the collection process, there are other factors that influence the income of collectors. Many respondents indicated that their current earnings are lower than in the previous years and see it as a direct result of the drop in the prices of paper products, which are their main source of income. In only one case, the respondent had an additional source of income from a spouse who is employed as a domestic worker.

It may also have been a case that some of the respondents wouldn't have disclosed their proper income for a number of reasons, namely fear of being robbed, distrust, or hope that the researchers could assist financially. The geographical remoteness of this region in relation to other more established industrial and commercial zones in the CMA also makes it difficult for them to travel in search of better prospects and more secure income. They therefore choose to recycle as it is the most convenient way of making some money irrespective of the problems encountered in the collection process and the small financial benefits derived at from this activity.

\section{CONCLUSION}

The future growth of the recycling enterprises is inextricably linked to market trends. However, interventionist government policies may have a positive impact on the growth of the industry locally against the background of poverty alleviation, employment, spatial inequalities and environmental concerns. There are no regulations in place in the study area to encourage households to recycle. Recycling is thus predominantly an activity that

\section{https://repository.uwc.ac.za/}


exists as a result of the needs of the poor and unemployed in the region, facilitated by the existence of the buy-back centres.

Recycling on the Cape Flats seems to be strongly underpinned by the notion of being an (informal) urban development process sustained by survivalist strategies embarked upon by the impoverished and unemployed urban poor as represented by the activities of micro-collectors. On the other hand, recycling can also be interpreted as a yardstick whereby the feasibility and sustainability of the very business can be judged. Based on the results of the survey, it seems as if the viability of buy-back centres is largely dependent on the reciprocal relationship between them and a collection-supply network.

There has been an overall increase in the demand for recycled material in the study area. The fluctuations in demand, however, affect the prices paid for recyclables and thereby reducing the ability of collectors to generate a sustainable income from waste collection. The supply of recycled material is also limited by the general lack of waste separation practices at the household and the local municipal level. In conclusion, the study has shown that many informal jobs can be created by recycling in this area and that it can be enhanced in a more structured way if local authorities can facilitate and probably provide incentives for waste recycling. Presently the industry operates solely on market-driven forces where prices fluctuate with the demand for waste material. This externality leaves everyone in the business chain of recycling very vulnerable, specifically the subsistence micro-collectors.

\section{ACKNOWLEDGEMENTS}

Thanks are due to Ronnie Donaldson for commentary and assistance in the shaping of this paper.

\section{REFERENCES}

Cape Times, 2004: "Mitchell's Plain baby boom, the fastest in the country", 30 September, 5 .

Chen, M.A., Jhabvala, R. and Lund, F., 2001: Supporting workers in the informal economy: A policy Framework. Paper prepared for the 1LO Task force on the Informal Economy.

City of Cape Town, 2004a: Status Quo Report: Integrated Waste Management Plan - Final Status report, Cape Town.

City of Cape Town, 2004b: Integrated Solid Waste Management Plan, Cape Town.

Durban Metro, 1999: Recycling Initiatives, Durban. Available on-line at http://ceroi. net/reports/Durban/issues/waste/recycle.htm.

Dyssel, M., 2001: Relationships between non-motorized subsistence transport and recycling in the Cape Metropolitan Area. Paper presented at the Fourth Biennial International conference of the Society of South African Geographers, July 2001, Goudini.

Government Gazette, 2000: White Paper on Integrated pollution and Waste Management for South Africa, No 20978, Government Printers, Pretoria.

\section{https://repository.uwc.ac.za/}


Gupta, S.K. and Sarkar, P., 2003: Extended Producer Responsibility, Toxics Link Recycling Report, 01/04/2003.

Hugo, L.M., 2004: Environmental management - An ecological guide to sustainable living in Southern Africa, Ecoplan, Pretoria.

Institute for Local Self Reliance, January 2002: Press release - Recycling sector has a 30-year record of impressive growth. Washington. Available on-line at: http://www. ilsr.org/recycling/recyclingma.htm.

Khan, F., 1996: Recycling as a matter of survival, Conserva, 11:1,16-17.

Miraftab, M., 2004: Neoliberalism and casualization of public sector services: the case of waste collection in Cape Town, South Africa. International Journal of Urban and Regional Research, Volume 28 (4), 874-892.

Scheinberg, A., 2001: Financial and Economic Issues in Integrated Sustainable Waste Management, Urban Waste Expertise Programme, Netherlands.

South African Yearbook 2004/2005, 2005: Government Communications, Pretoria.

US Environmental Protection Agency, 1995: Decision-maker's Guide to Solid Waste Management (2 ${ }^{\text {nd }}$ Edition), (EPA 530-R-95-023), Washington, DC. 